\title{
A parsimonious model to forecast financial distress, based on audit evidence
}

Carlos Piñeiro Sánchez. Faculty of Economics and $\mathrm{Bu}-$ siness, University of a Coruña carpi@udc.es

Pablo de Llano Monelos Faculty of Economics and $\mathrm{Bu}-$ siness, University of a Coruña pablo.de.1lano@udc.es

Manuel Rodríguez López Faculty of Economics and Business, University of a Coruña marod@udc.es

\section{Abstract}

This paper provides evidence that audit reports convey relevant evidence for inferring the existence of underlying, unrevealed, financial imbalances. Unlike previous works, which studied US listed-firms bankruptcy, our research deals with Spanish non-financial SMEs under financial stress. Our results indicate that the audit of distressed SMEs has several distinctive features: higher auditor rotation, more qualified reports, and non-compliance with deadlines to approve and file the annual financial statements. We use this evidence to build and test a parsimonious and reliable forecast model. Several implications for auditors' independence, information quality, and failure forecast are discussed.

Keywords: financial distress, failure forecast, audit quality, logit regression. 


\section{Un modelo simple para pronosticar las tensiones financieras, basado en evi- dencias de auditoría}

\section{Resumen}

Este artículo proporciona evidencia de que los informes de auditoría contienen evidencias relevantes para inferir la existencia de disfunciones financieras latentes. A diferencia de trabajos previos, que han estudiado el fallo financiero en grandes empresas cotizadas, fundamentalmente de EE.UU., nuestro trabajo se centra en Pymes españolas sometidas a tensiones financieras latentes. Nuestros resultados indican que la auditoría de las Pymes financieramente desequilibradas posee varias características distintivas: una tasa mayor de rotación de auditores, más informes con salvedades e incumplimientos de los plazos legales para aprobar y registrar las cuentas anuales. Empleamos estas evidencias para construir y verificar un modelo simple, o parsimonioso, capaz de anticipar eficazmente esas disfunciones. Se discuten las implicaciones para la independencia del auditor, la calidad de la información, y el pronóstico del fallo.

Palabras clave: tensión financiera, pronóstico de fallo, calidad de la auditoría, regresión logística.

\section{Introduction}

When a company disappears or becomes insolvent there are serious implications for many external and internal economic agents; obviously, shareholders but also moneylenders, clients and suppliers, employees and the authorities themselves. That's why business failure has been a recurrent topic in literature, and the development of forecast methods has been one of the priority objectives for Financial Research.

There are several mathematical and heuristic methodologies suitable for this purpose, e.g. multiple discriminant analysis (MDA) (Altman, 1968): logistic regression (logit) (Martin, 1977; Beaver, 1966; Ohlson, 1980): Bayesian analysis and several artificial intelligence (AI) applications. Most of them use financial ratios as independent variables, thus they rely on the quality of accounting information. 
An exhaustive conceptual framework has been developed to enhance accounting information quality. The International Financial Reporting Standards (IFRS) define common standards for the format and content of financial statements, for the valuation and specification of the assets, and generic principles to guarantee the quality of accounting information; they have been adopted by more than one hundred countries around the world, including Spain.

Notwithstanding these rules, the external audit is the main guarantee of the quality and reliability of financial information. Auditors are committed to issue an expert opinion about whether financial statements have been developed according to generally accepted accounting principles (GAAP): and convey a fair expression of the financial and economic situation of the company. Distressed companies usually try to avoid disclosures by making abnormally high accruals (Herbohn and Ragunathan, 2008): but these adjustments are not easy to interpret (Arnedo et al., 2005): an increase of accounts receivable might be interpreted as a sign of the growth in sales but, also, might be caused by changes in sales policies aimed at, precisely, hiding declining sales. Of course, these accruals may lead to qualified reports (Francis and Krishnan, 1999); thus, distressed companies have an incentive to hire low quality auditors, and to undermine auditors' independence in order to "manage" audit reports. Previous research has found evidence supporting that latent financial distress manifests itself, indirectly, in certain anomalous external events related to the auditing process such as systematic auditor changes, reluctance to hire auditors from the national firms or the big four firms, and correlations between auditor changes and issuing clean reports (Schwartz and Menon, 1985; Schwartz and Soo, 1995; Ruiz and Gómez, 2001)

This paper gives an in-depth examination of both the conduct of the auditor and the signals stemming from the audit of accounts, in the particular case of the non-financial SMEs under financial distress. We will provide a parsimonious forecasting model, capable of assessing effectively the financial health of the company and to provide a reliable estimate of the likelihood of its financial failure. This model is a novel contribution as the previous research had been focused on the descriptive study of the audit features in financially instable companies, especially in AngloSaxon countries. However, there has been no consideration on using those features to establish a complementary analysis to those performed by the conventional MDA or logit models, which are based on financial ratios; this is particularly true in the case of small companies. Our research provides a reliable forecast model that achieves a high hit rate and that depends on objective variables derivable 
from the audit reports; this model provides useful results to clarify the effects of information asymmetries and the balance of power between the auditor and his/her client with respect to the quality of the general accounting information and, particularly, of the audit report. In addition, it formalises the logical links between the content of the audit report, the quality of the accounting information and the internal financial imbalances.

A key contribution of our work is its approach, which is focused on the analysis of failure risks in SMEs, which are usually pushed into the background by the emphasis on the listed companies research. This is a very valuable contribution as SMEs make up the bulk of the Spanish business fabric. Also, information asymmetries and imperfections are much more evident in them.

A large majority of the early research in this field comes from countries based on common-law accounting systems. Despite the standardisation brought forward by the IFRS, the accounting conceptual framework, the business culture and technical auditing rules are still somehow different in the continental countries, and especially Spain (Arnedo et al., 2005): for example, qualified reports are more frequent in Spain compared to the US, not because Spanish companies breach the accounting rules more often, but because most of the qualifications in the US correspond to exceptions to the going concern principle (Carcello and Palmrose, 1994). The evidence provided by our work allows us to reinterpret this early research in accordance with the particular features of the Spanish legal framework and provides a base for the comparative analysis of the Spanish SMEs against other types of companies.

\section{Background}

The core of business failure research is linked to the accounting tradition and explores the possibility of forecasting business failure events based on the financial information released by companies. The first contributions applied univariate statistical methods to search for statistically significant differences between healthy and bankrupt companies (Beaver, 1966). However, it was not long before the business failure was described as a complex process caused by -and manifested itself in- multiple variables. Since the release of Altman's research papers (Altman, 1968) the dominant methodological approach has been applying multivariate methods -especially, multiple discriminant analysis (MDA): and the logit or probit models (Ohlson, 1980)- on time-series samples of healthy and bankrupt compa- 
nies. These models use financial ratios as independent variables, and in some cases also market information (e.g. profitability, risk, PER, price/book value, etc.) and macroeconomic indicators to express systematic risk factors (Rose et al., 1982; Mensah, 1984; Liu, 2004).

Recently, a promising breakthrough has been achieved with the application of heuristic methods: some studies try to enhance $a$ priori failure probabilities using $a$ posteriori information applying Bayesian inference (e.g. Sarkar and Sriram, 2001); cooperative and team work have been also used to deal with multicriteria problems involving qualitative variables (Sun and $\mathrm{Li}, 2009$ ). A relevant research program develops artificial intelligence -based on tools to improve failure forecasts-, e.g. support vector machines (SVM) (Kim and Sohn, 2010): expert systems and artificial neural networks (Messier and Hansen, 1988; Bell et al., 1990; Serrano and Martín del Brío, 1993; Rodríguez et al., 2010).

Whatever the methodology, the inference process is based on the companies' public information, which is a variable combination of accounting information, market information, and qualitative measures about the quality of management (Peel et al., 1986; Keasey and Watson, 1987). External audit plays a critical role as the main guarantee of the quality of accounting data.

Auditors are committed to reduce the information asymmetries between managers, shareholders, and external users of accounting information, by ensuring that this information is reliable and revealing relevant GAAP non-observances. Previous works have found a correlation between discretionary accruals, auditor's quality, financial distress, and qualified reports (Butler et al., 2004; Arnedo et al, 2005; Blay, 2005): distressed companies have an obvious incentive to conceal data and references whose interpretation may be unfavourable, hiding them within the flow of information directed to investors, suppliers and other external groups (McKeown et al., 1991); in some cases they can simply obviate these references, but they frequently make use of accruals to smooth down the changes in critical financial magnitudes, e.g. sales, bad debts or costs (Arnedo et al., 2005). If auditors do perform well, abnormal accruals, GAAP non fulfilments, and relevant uncertainties should be correlated with qualified reports, even with denials if the company hinders the work of the auditor (Citron and Tafler, 1992; Hopwood et al, 1989; Herbohn and Ragunathan, 2008); thus, modified reports might be interpreted as external signs of latent financial imbalances (Bushman and Collins, 1998): and also convey information about audit quality. 
A part of the research has found little evidence of this relationship, and the hypothesis that qualifications do not have specific information content has taken hold over the years (Elliot, 1982; Dodd et al., 1984; Bessell et al., 2003). The so-called neutrality hypothesis has been used as an argument to explain the apparent low capacity of the accounting audit to highlight issues affecting the going-concern (Altman and McGough, 1974; Venuti, 2004). However, discarding the informational content of the qualifications is a very demanding assumption; it implies that the audit report does not provide relevant evidence to interpret the financial situation of the company, and figure out the capacity of the company to survive as an economic unit, not even when the auditor highlights relevant breakdowns or reveals uncertainties. Several works have found that investors perceive audit reports as informative (Dopuch et al., 1986; Loudder et al., 1992).

In fact, an auditor is not engaged to act as a financial analyst and search for financial imbalances, but only to express a professional opinion about the fairness of financial statements. A clean report is compatible with severe financial imbalances as long as the auditor considers that GAAP has been rigorously applied, and the information conveyed by the annual accounts can be considered reliable. Actually, only a few critical uncertainties are directly connected to the company's survival, and even in these cases, the company may be able to avoid failure by applying major corporate restructuring plans. In the Spanish case, art. 2.1 of the Law on Account Auditing -redrafted by Law 12/2011 ${ }^{1}$ - has modified the criteria to reveal uncertainties by applying a restrictive interpretation of the auditor's functions: up to this day, uncertainties had to be specifically recorded as qualifications. However, the new Spanish auditing standards establish that, if the uncertainty is properly described in the Annual Report, the audit report will just include an emphasis paragraph. A qualification or, when appropriate, an adverse opinion will be issued only when the representativeness of the annual accounts is slackened because the uncertainty is insufficiently or imperfectly expressed.

\footnotetext{
${ }^{1}$ The spanish regulatory framework has gone through relevant changes to update and adapt to the international accounting regulations; in the case of audit, several changes came after incorporating the Directive 2006/43/CE into the national law. The Law 12/2011 of 30 June modifies many aspects of the old Law 19/1988. Among these aspects, we can mention the principles influencing the auditor's opinion when there are uncertainties that may affect the going concern principle.
} 
Moreover, the nature and financial implications of the qualifications may be very different $^{2}$; their evaluation also depends on several subjective factors, e.g. auditors' knowledge, thoroughness and materiality levels applied (Francis and Krishnan, 1999). In fact, discussing the forecasting relevance of qualifications and modified audit reports implies making judgments about audit quality, and auditor's independence.

Although they are supposed to act as independent experts, the company discretionally hires auditors; this places them in a potentially tense position with their clients (Krishnan and Krishnan, 1996; Blay, 2005). Economic or interest relationships such as having common clients- might undermine the auditor's independence, and even distort the report (Simunic, 1984; Robinson, 2008).

Among the incompatibility cases, the Law 12-2010 includes providing legal services -also the development of Information Technology platforms and, we must understand, any type of consultancy service in general- to the company subject to auditing (or its affiliates) except when the services are provided by a different legal entity managed by a different board of directors, and/or when those services are related to issues with very little impact on the annual accounts subject to analysis. The receipt of professional fees is also forbidden except when they are of relatively minor importance compared to the total income of the auditor. However, even the smallest corporation groups are made up of numerous entities, managed by different boards but connected by the same capital links; accounting and auditing firms are not an exception. It is also well known that the auditor's fees must be established before starting the activity and cannot depend on, or be influenced by, the fact that other services are being hired. This is strictly prohibited; however it's no wonder that this issue is subliminally present in the contract negotiations between the company and the auditor, as well as in the creation of the corresponding letter of engagement.

Some evidence indicates that informational asymmetries and the strategic approach play an important role in the assessment of the material evidence and the

\footnotetext{
${ }^{2} \mathrm{Also}$ as the audit report is released together with and inseparably from the annual financial statements, it is difficult to evaluate to which extent the market reaction is caused either by the content of the report or by a diagnosis based on the primary accounting information itself or by a combination of both (Elliot, 1982) (Dodd, Dopuch, Holthausen, \& Leftwich, 1984).
} 
opinion-making process (Citron and Taffler, 1992; Krishnan and Krishnan, 1996; Tucker and Matsumura, 1998; Chen et al., 2009). The opinion-making process is determined by the effect the auditor expects his report will have on the way the company interacts with its surroundings, particularly the effect on the quotes of publicly traded companies. Once again, because of the informational asymmetries, auditors might be reluctant to release opinions that may reveal latent financial dysfunctions and precipitate the failure; for example, by instilling suspicion into the moneylenders or by altering the materials supply or by increasing the interest rates applied in several refinancing operations. Kida (1980) suggested that even when it is widely assumed that the company will fall into an imminent business failure, auditors may decide not to issue an opinion with critical uncertainties with respect to the continuity of the company. This is the basis of the hypothesis of self-fulfilling prophecy: under some circumstances, auditors might avoid disclosures in fear that their opinion can precipitate the failure. Some researchers claim that the auditors may have the tendency to interpret evidence optimistically, that is, to give more weight to the evidence supporting the survival of the company.

The bundle of informational interchanges between the auditor, his client and the market is extremely complex, to the point that the imbalances and the lack of confidence may be transmitted to the auditor's client and end up altering his market prices and volatility (Hillinson and Pacini, 2004). Game theory has been applied to describe the interactive nature of this relation, and the underlying information asymmetries (Fellingham and Newman, 1985; Teoh, 1992; Matsumura et al., 1997; Tucker and Matsumura, 1998).

This research program has supplied a deep knowledge about auditors' behaviour in disrupted companies. Companies that change their auditor several times obtain qualified audit reports less frequently (Lennox, 2000) whilst it has been observed that distressed companies change their auditor more frequently than average (Schwartz and Menon, 1985; Schwartz and Soo, 1995; Ruiz and Gómez, 2001). Likewise, auditors tend to issue clean reports when there are reasons to be concerned about whether the client will not renew the contract or will cancel it prematurely (Blay, 2005).

In fact, imbalanced firms have incentives to select vulnerable auditors, and to apply rotation strategies in order to gain a dominant position over the auditor, and "plan" the reports (Francis and Krishnan, 1999; Chen et al., 2009); this action is often 
related to an attempt to hold back the release of modified opinion reports, and/or going-concern disclosures. From this point of view, the trend to make short-term arrangements could be interpreted as an attempt to disable the effectiveness of the legal limitations with respect to the minimum duration of the audit contracts ${ }^{3}$.

Several countries have implemented mandatory changes in order to avoid the development of economic dependencies and/or an excessive closeness to the client, which might undermine auditor's independence ${ }^{4}$; this can create conflicts of interest, in the same way that the ratings issued by rating agencies may be biased by the economic interests of its owners, who are also profit-guided investors. However, evidence on the so-called opinion purchase is inconclusive and requires a more specific study to clarify the extent of the auditor's vulnerability with respect to his economic dependence, the size and diversification of his client portfolio and his degree of internationalisation. A low rotation might be interpreted also as a sign of lack of independence (Beck et al., 1988): but evidence in this area is inconclusive (e.g. Carcello et al., 2003)

\section{Methodology}

\section{Dependent variable}

Bankruptcy is usually the word we use to describe the situation in which the company is unable to make its payments. This definition is too broad for our purposes because financial distress situations do not necessarily lead to insolvency, or the demise of the company; on the other hand, covenants to extend the payment terms may not be revealed to the environment, and this prevents any exhaustive classification. In this work we define distressed companies as those who have filed for bankruptcy protection, but have not been liquidated; this allows for a rigorous and exhaustive classification in two categories: healthy (0) and distressed companies (1). Then, our model helps forecast the likelihood that a company suffers financial tensions that prevents timely payments due to liquidity problems, even if this situation does not cause an irreversible bankruptcy.

\footnotetext{
${ }^{3}$ Contracts in Spain must last for a minimum of three years (art. 8 quarter of the Law 12/2010); during that time, the contract cannot be cancelled without good cause.

${ }^{4}$ Mandatory rotation does not exist in Spain.
} 
This specification is also coherent with the usual practice of filing for filed for bankruptcy protection (nowadays, defined as voluntary bankruptcy proceedings for creditors in Spanish law) to avoid criminal responsibility in imminent bankruptcy situations (Pozuelo et al., 2010); if this line of reasoning is correct, the majority of the companies under financial stress will urge bankruptcy proceedings, thus improving the reliability of our model.

\section{Independent variables}

Assessing the information content of the audit reports and the ability of auditors to convey relevant signals to forecast business failure is extremely controversial. Inductive reasoning is required to deduce whether the qualified opinions and/or the uncertainties proposed in each case by the auditor are helpful to assess the risks. This significance is only known in a reliable way ex post. Therefore, despite having made considerable advances in the codification of qualifications regarding their potential financial impact, in this study we use a simplified set of explanatory variables inspired by three principles: objectivity, simplicity, and direct derivability from the audit reports. All of the variables are supported by previous research, although cited works were performed on samples of large, publicly quoted, firms.

- Proportion of audited years (pyears). This variable allows us to control the company's size, which is a documented factor of financial risk ${ }^{5}$ - and enhance the expression of certain anomalous behaviour, as the non-compliance with the auditing obligation. This variable is not interpreted as a predictive factor, bus as a control factor.

- Number of different auditors hired (naudit). Previous research indicates that increased rotation is more frequent in distressed firms trying to influence the report.

- Temporal matches between auditor changes and changes in the opinion (tmatch).

- Average length of auditors' contracts (lengt).

- Ratio between qualified audit reports and total number of reports (pqual).

- Number of critical qualified audit reports (pcqual). In this case, critical refers to i) uncertainties relevant to the company's survival; and ii) non-

\footnotetext{
${ }^{5}$ In Spain, mandatory audit is defined in terms of number of employees, assets, and turnover. Larger companies are usually required to be audited, while SMEs' meet these conditions only irregularly.
} 
compliances with the GAAP that are empirically related to business failure situations, e.g. irregular capitalisation of expenses.

- Auditor type (auty). The vulnerability of the auditor under pressure from the company is especially related to his high or low profile, as well as the degree of his economic dependence. Therefore, the interactions may be less frequent in the case of auditors who are members of the firm and even less frequent in the case of multinational accounting firms. This variable has been computed as categorical (individual, local/national society, big four)

- Explicit obstructionism (obstr): such as lack of collaboration by the company, and massive failure of mailing circularisation and balance confirmation.

- Non-compliance with the obligation of auditing the accounts (nonau).

- Delays in the filing of annual financial statements in the Commercial Registry (delfil).

\section{Sample}

Data was collected through a balanced sampling from non-financial audited companies with no more than a hundred employees, and whose central offices were located in Galicia. These firms were required to be at least five years old, to avoid any confusion effect caused by the well-known anomalous morbidity rate in young businesses; besides that, given the nature of the independent variables of our work, we also excluded those companies with less than two audit reports available ${ }^{6}$. Sampling was carried out according to the information supplied by the SABI (Iberian Balance-sheets Analysis System) and the Commercial Registry for the period $1998-2008^{7}$.

Preliminary statistical analysis showed extremely anomalous failure rates in building industry and real estate activities; this bias was caused by external exceptionally adverse conditions which were unrelated to the relationship we were modelling, therefore those activities were also excluded. The final sample was made up of 98 companies.

\footnotetext{
${ }^{6}$ In the logit model, the number of available audit reports is controlled by the variable pyears.

${ }^{7}$ We ruled out the year 2009 because at the time when the basic sampling was done, the accounting information for this year was not available in the general statistics from the SABI database. Therefore, using that year would mean to have to restrict the sample extremely, affecting both the healthy and bankrupt companies.
} 


\section{Method}

Given the dichotomous character of the dependent variable and the nature of the independent variables, our study is based on a logistic (logit) regression model. This allows us to estimate the probability of a company - with particular characteristics regarding the auditing process (number of reports, nature and proportion of qualifications, degree of compliance with the registry obligations, etc.) - being subject to financial dysfunctions driving the company to business failure. Logit models do not depend on restrictive assumptions with respect to the joint distribution of the probability of the independent variables; this is a notable strength because financial ratios and most of real empirical variables do not fit Gaussian distributions.

Let $\mathrm{Y}_{\mathrm{j}}$ be a binary variable expressing the financial health of the $\mathrm{j}^{\text {th }}$ company (zero if $\mathrm{j}$ is empirically healthy, and one if $\mathrm{j}$ has filed for bankruptcy protection); let $\mathrm{X}_{\mathrm{h}}$ be the independent variable $\mathrm{h}^{\text {th }}$. The logit model can be expressed as:

$$
p=P\left(Y_{j}=1\right)=\frac{1}{1+e^{-z_{j}}}
$$

where $z_{j}=\beta_{0}+\beta_{1} \cdot X_{1 j}+\beta_{2} \cdot X_{2 j}+\ldots+\beta_{n} \cdot X_{n j} \cdot$. The resulting $p$-value is the estimated probability of an observation $\mathrm{j}$ with profile $X_{\mathrm{j}}=\left\{\mathrm{X}_{1 \mathrm{j}}, \mathrm{X}_{2 \mathrm{j}} \ldots \mathrm{X}_{\mathrm{nj}}\right\}$ ending in business failure.

\section{Results and discussion}

The model has been estimated following a stepwise procedure, in order to select the most significant subset of predictors. Three variables are significant in the final model:

- Non-compliance with deadlines to approve and file annual financial statements (delfil). According to our results, this is the more relevant variable, given the associated odds-ratio $(\mathrm{OR}=2.77 \mathrm{E}+09)$.

- The average length of the contracts (length): with a negative coefficient and an odds-ratio less than one; therefore, the longer the contract is, the lower the odds of the company suffering financial distress. Our results indicate that each additional year corresponds to a decrease of $27 \%$ in the likelihood.

- The proportion of qualified opinion reports (pqual); the odds-ratio is 
statistically different from one, given the results of the Wald test and the extreme values of the confidence interval for the odds-ratio, thus we can reliably assume that this variable helps evaluate the relative risk of a company receiving additional modified reports. Our results indicate that each of these modified opinions increase the risk to $3 \%$.

All these coefficients are statistically significant for $\alpha=0.01$ and their signs are coherent with previous research and with financial theory. The average length of the contracts is negatively related to the estimated failure odds. Therefore, these events are ceteris paribus, less frequent among companies that have long contracts or, in their absence, whose policy is to renew them regularly. On the contrary, the estimators corresponding to the proportion of modified opinion reports and noncompliance with deadlines to pass and file annual financial statements are positive. Accordingly, the accumulation of qualified opinion reports and/or reiterative breaches of the registry obligations appear to be clear warning signals.

Figure 1

Descriptive statistics (independent variables)

\begin{tabular}{c|c|c|c|c}
\hline & \multicolumn{2}{|c|}{ Healthy } & \multicolumn{2}{c}{ Distressed } \\
\hline & Average & SD & Average & SD \\
\hline pyears & 0.57 & 0.04 & 0.38 & 0.04 \\
\hline length & 3.76 & 0.54 & 2.83 & 0.27 \\
\hline Pqual & 17.88 & 9.87 & 56.94 & 8.08 \\
\hline pqualg & 3.65 & 2.50 & 16.79 & 4.46 \\
\hline Obstru & 1.10 & 0.10 & 1.13 & 0.09 \\
\hline nonau & 1.20 & 0.13 & 1.38 & 0.13 \\
\hline
\end{tabular}

\begin{tabular}{c|c|c|c|c|}
\hline & \multicolumn{2}{|c|}{ Healthy } & \multicolumn{2}{c|}{ Distressed } \\
\hline & Average & SD & Average & SD \\
\hline delfil & 1.13 & 0.09 & 1.10 & 0.10 \\
\hline tmatch & 0.10 & 0.10 & 0.63 & 0.13 \\
\hline propcam & 0.26 & 0.09 & 0.33 & 0.06 \\
\hline naudit & 1.41 & 0.12 & 1.59 & 0.13 \\
\hline auty & 2.20 & 0.11 & 1.86 & 0.09 \\
\hline & & & & \\
\hline
\end{tabular}

Altogether the final model turns out to be significant (figure 2 and figure 3 ). The -2LL statistic is relatively small and the generalised coefficients of determination, particularly Nagelkerke's $\mathrm{R}^{2}$, have satisfactory values for an empirical exploratory study like this - as it is well-known, Cox's and Snell's $\mathrm{R}^{2}$ is not strictly bounded to be between zero and one. The same conclusion can be deduced from Hosmer's and Lemeshow's statistic and the specificity and sensitivity levels, as well as from the total percentage of success in the classification (figure 4). 
Figure 2

Model's coefficients

\begin{tabular}{c|c|c|c|c|c|c|c|c}
\hline $\begin{array}{c}\text { Model's } \\
\text { coefficients }\end{array}$ & B & E.T. & Wald & gl & Sig. & Odds-ratio & \multicolumn{2}{|c}{$\begin{array}{c}\text { I.C. 95.0\% for } \\
\text { OR }\end{array}$} \\
\hline length & -0.32 & 0.14 & 4.96 & 1 & 0.03 & 0.73 & 0.55 & 0.96 \\
\hline pqual & 0.03 & 0.01 & 14.39 & 1 & 0.00 & 1.03 & 1.01 & 1.04 \\
\hline delfil & 21.74 & 8642.69 & 0.00 & 1 & 1.00 & $2.77 \mathrm{E}+09$ & 0.00 &. \\
\hline Constant & -22.16 & 8642.69 & 0.00 & 1 & 1.00 & 0.00 & & \\
\hline
\end{tabular}

Figure 3

Model statistics

\begin{tabular}{c|c|c|c}
\hline \multicolumn{3}{|c}{ Hosmer and Lemeshow test } \\
\hline Step & Chi-square & gl & Step \\
\hline 3 & 6.1104 & 8 & 3 \\
\hline
\end{tabular}

\begin{tabular}{c|c|c|c}
\hline \multicolumn{4}{|c}{ Models Summary } \\
\hline $\begin{array}{c}\text {-2 log of } \\
\text { likelihood }\end{array}$ & $\begin{array}{c}\text { Cox's and } \\
\text { Snell's R }\end{array}$ & $\begin{array}{c}\text { Nagelkerke's } \\
\mathrm{R}^{2}\end{array}$ & Sig. \\
\hline 74.8949 & 0.4632 & 0.6176 & 0.6349 \\
\hline
\end{tabular}

Figure 4

Table of classification

\begin{tabular}{|c|c|c|c|c|}
\hline \multirow{2}{*}{ Observation } & \multicolumn{2}{|c|}{ Forecast } & Correct \\
\cline { 3 - 4 } & & Healthy & Distressed & Percentage \\
\hline \multirow{2}{*}{ Observed } & Healthy & 42 & 7 & 85.71 \\
\cline { 3 - 4 } & Distressed & 13 & 36 & 73.47 \\
\hline \multicolumn{2}{|c|}{ Global percentage (cut-off value $=0.5)$} & 79.59 \\
\hline
\end{tabular}

Figure 5

Correlations matrix

\begin{tabular}{|c|c|c|c|c|}
\hline & Constant & pqual & delfil & Length \\
\hline Constant & 1.000 & .000 & -1.000 & .000 \\
\hline Length & .000 & .102 & .000 & 1.000 \\
\hline Pqual & .000 & 1.000 & .000 & .102 \\
\hline Delfil & -1.000 & .000 & 1.000 & .000 \\
\hline
\end{tabular}

Let us look into our results in more detail. Our findings support the view of the relationships between the company and the auditor as being governed by informational asymmetries; this context is suitable to implement opportunistic strategies aimed at biasing the collection and interpretation of audit evidence, and the opinion- ma- 
king process. First, the duration of the contracts - which is a measure inverse to the auditor turnover rate - is linked to the company's financial health. Healthy companies are prone to rely on the same auditor to make the reports during longer periods of time, as well as hire the services of national and international accounting firms. On the contrary, the retrospective analysis on the conduct of companies under financial distress reveals that their auditing process is more irregular in subjective (responsible auditor) and objective (number of audit reports, sense of the report, number of qualifications and severity of the uncertainties pointed out by the auditor) terms. These results extend previous evidence reported by Carcello et al. (2003): who found that auditors who had served their clients for more than three years were more likely to issue a going-concern opinion, all other things being equal; while some priceless works suggest that audit effectiveness might decrease after the first year of the contract (Beck et al., 1988): our results indicate that longterm contracts do not seem to undermine auditors' independence.

Available evidence indicate that distressed firms change auditors more frequently than others (Schwartz and Menon, 1985; Schwartz and Soo, 1995; Ruiz and Gómez, 2001; Chen et al., 2009); this corroborates previous results (e.g. Simunic, 1984 and Robinson, 2008) that warn the existence of scenarios where the auditor's independence is threatened by power and/or economic dependence asymmetries that may leave him in a vulnerable position. We think it is realistic to say that distressed firms try to prevent the auditor from revealing their financial imbalances -through qualifications and/or uncertainties- with the help of their hiring policy. It is interesting to point out that the variables "proportion of qualified audit reports" and "average length of the contracts" have a small empiric correlation but are positive $(\rho=0.102)$ and therefore we suggest a detailed study to check if the accumulation of qualifications is actually less prominent in companies with a higher auditor turnover rate. Unlike previous works, we have not found any evidence regarding the relationship between auditor quality, auditor vulnerability, and the client's financial stability. Finally, none of the situations grouped in the variable obstr has led to a disclaimer of opinion; we must conclude that the auditors did not perceive any sign of lack of cooperation from the firms.

On the contrary, the odds-ratio associated with the variable pqual appears to be abnormally low. There is a lot of empirical evidence concerning the relationship between financial distress, accruals, and the issuing of qualified opinions, therefore our result might demand a more detailed analysis. Until 2010 the Spanish Audit Law did not make an explicit distinction between GAAP non-fulfilments and un- 
certainties, therefore our variable pqual combines multiple circumstances that may have little relation to underlying financial distress scenarios. Modified reports are much more frequent in Spain than in the US because Spanish law allows issuing qualified opinions not only when the firm faces relevant uncertainties, but also when a GAAP non-fulfilment is detected, and even when the auditor decides to convey some information that he or she believes relevant. For example, Spanish auditors usually include a formal qualification the first time they audit a firm, stating that they did not attend the stock control; this implies a qualified report but, obviously, is not supposed to be connected with a higher financial risk. It is likely that many of the recorded qualifications are irrelevant from the standpoint of financial diagnosis; this might have biased the estimation of the odds-ratio for this variable.

It is important to emphasize that external users should not pay attention to how serious the qualifications seem to be, but to the general attitude of the company as reflected by all the available audit reports: according to our model, the accumulation of qualifications, even if they seem to be irrelevant, is indicative of the existence of underlying financial imbalances that may lead the firm to bankruptcy. This does not mean that critical qualifications and going-concern uncertainties are irrelevant, but that they can be caused by transitory circumstances -such as an uncertaintythat the company may overcome subsequently. On the contrary, recurrent qualifications are indicative of a chronic, unsolved distress.

According to our opinion, it is really important for the financial practice to determine the technical criteria for the issue of qualified opinions and the assessment on how important they are. Auditing Standards have pushed the uncertainties into a simple emphasis paragraph and, in our opinion, this may be confusing to some extent. At least in Spain, external users usually interpret a clean report as a sign of normality and well-doing in the company, because the qualifications and uncertainties are related to underlying financial imbalances and risks (Hopwood et al., 1989). The loss of information can be especially intense for those investors using web syndication services, or AI-based semantic tools; in these cases the uncertainties could be underestimated or even go unnoticed if the information of the Annual Report is not comprehensive enough, or does not highlight the key procedures, or underestimates the adverse scenarios.

We haven't found any evidence for the so-called self-fulfilling prophecy -the assumption that the failure is caused by the auditor's opinion-. Because of the finan- 
cial logic, this hypothesis (in fact a post hoc, ergo propter hoc inference) leads to an untenable sophism. It is possible that an imprudent or ill-considered opinion may aggravate the financial imbalance, however we cannot forget that the failure has been caused by real financial dysfunctions preceding the audit report and therefore, not caused by the latter. The auditor fulfils his or her duty to the company and to society when he or she reveals the uncertainties that may plausibly affect the business continuity; the general omission of these references could cause a moral risk incompatible with the trust governing the trade activity.

\section{Conclusions}

Our study provides a forecast model designed to infer the latent financial imbalances in small and medium enterprises that are not traded on a secondary market; independent variables are quantitative and qualitative measures directly derived from the external audit process, and audit reports themselves. The analysis of audit reports confirms that financially imbalanced firms tend to change auditors more frequently than others (Schwartz and Menon, 1985; Schwartz and Soo, 1995; Ruiz and Gómez, 2001); auditors are hired for shorter periods of time, and this behaviour can be interpreted as an attempt to lessen the levels of thoroughness and independence. However, empirical evidence suggests that these attempts are fruitless: distressed firms receive more qualified opinion reports, and their auditors reveal more going-concern uncertainties. It is noticeable that the average proportion of qualified reports reduces in line with the duration of the contracts: this finding is in line with previous results discussed in literature, but it can also be interpreted as a sign of collusion between auditors and their clients.

Given these results, it is not surprising that distressed companies have a tendency to disregard the deadlines for registration of the CCAA and the audit report, and even to breach the mandatory external audit. This attitude must be interpreted as an extreme attempt to prevent financial imbalance and/or discretional accruals being disclosed, and therefore corroborates auditor's independence.

The logit model achieves a hit rate of over $80 \%$ using a small number of external objective indicators; therefore, it strictly complies with the principle of simplicity or parsimony. The most valuable external signs of financial distress are i) non-compliance with deadlines to file the annual financial statements; ii) repeated changes in auditors (short-term contracts, and high rotation rate); and iii) accumulation of qualified opinion reports over time. 
We believe that improving the codification of the qualifications can enhance the accuracy of the model; as we have discussed, most of the qualifications registered by Spanish auditors are not directly connected with financial distress. A promising approach is to develop a semantic classification rule, which is able to diagnose and label each qualification, according to its effect on financial stability (Butler et al, 2004). Model must also be enhanced to support the estimation of intertemporal odds: a specification of the time structure of financial distress risk might be useful to assess the severity of the imbalances, and to estimate the remaining time before they become irreversible.

\section{References}

Altman, E. (1968). Financial ratios, discriminant analysis and the prediction of corporate bankruptcy. Journal of Finance 23 (4): 589-609.

and T. McGough (1974). Evaluation of a company as a going concern. Journal of Accountancy: 50-57.

Arnedo, L., F. Lizarraga and S. Sánchez (2005). Ajustes discrecionales y comportamiento del auditor en empresas en proceso de fracaso. Una aplicación al caso español. XIII Conference of AECA. Available from: http://www.uv.es/ catedra-aeca/workshop/files/files/SP2_Arnedo_Lizarraga_Sanchez.pdf

Beaver, W. (1966): Financial ratios as predictors of failure. Empirical research in accounting: selected studies. Journal of Accounting Research Supplement 4 (3): 71-111.

Beck, P., T. Frecka and I. Solomon (1988). An empirical analysis of the relationship between MAS involvement and auditor tenure. implications for auditor independence. Journal of Accounting Literature (7): 65 - 84.

Bell, T., G. Ribar and J. Verchio (1990). Neural nets versus logistic regression. A comparison of each model's ability to predict commercial bank failures. In R. P. Srivastava, X Auditing Symposium Deloitte \& Touche. Kansas. University of Kansas. Symposium on Auditing Problems: 29-53. 
Bessell, M., A. Anandarajan and A. Umar (2003). Information content, audit reports and going-concern. An Australian study. Accounting and Finance (43): 261-282.

Blay, A. (2005). Independence threats, litigation risk, and the auditor's decision process. Contemporary Accounting Research (22): 759-789.

Bushman, T. and D. Collins (1998). Uncertainty about litigation losses and auditor's modified audit reports. Journal of Business Research (43): 57-63.

Butler, M., A. J. Leone and M. Willenborg (2004). An empirical analysis of auditor reporting and its association with abnormal accruals. Journal of Accounting and Economic 37 (2): 139-165.

Carcello, J. V. and Z. V. Palmrose (1994). Auditor litigation and modified reporting on bankrupt clients. Journal of Accounting Review 32 (Supp. Studies on Accounting, Financial Disclosures, and the Law): 1-30.

D. R. Hermanson and T. L. Neal (2003). Auditor reporting behavior when GAAS lack specificity. the case of SAS No. 59. Journal of Accounting and Public Policy (22): 63-81.

Chen, C., G. Yen and F. Chang (2009). Strategic auditor switch and financial distress prediction. Empirical findings from the TSE-listed firms. Applied Financial Economics (19): 59-72.

Citron, D. and R. Taffler (1992). The audit report under going concern uncertainties. An empirical analysis. Accounting \& Business Research (22): 337-345.

Dodd, P., N. Dopuch, W. Holthausen and R. Leftwich (1984). Qualified audit opinions and stock prices. information content, announcement dates, and concurrent disclosures. Journal of Accounting and Economics (6): 3-39.

Dopuch, N., R. Holthausen and R. Leftwich (1986). Predicting audit qualifications with financial and market variables. The Accounting Review 62 (3): 431453. 
Elliot, J. (1982). Subject to audit opinions and abnormal security returns. Outcomes and ambiguities. Journal of Accounting Research (20): 617-638.

Fellingham, J. and P. Newman (1985). Strategic considerations in auditing. Accounting Review (60): 639-650.

Francis, J. and J. Krishnan (1999). Accounting accruals and auditor reporting conservativism. Contemporary Accounting Research 16 (1): 135-165.

Grice, J. S. and M. T Dugan (2001). The limitation of bankruptcy prediction models. Some cautions for the researcher. Review of Quantitative Finance and Accounting (17): 151-166.

Herbohn, K. And V. Ragunathan (2008). Auditor reporting and earnings management. some additional evidence. Accounting \& Finance 48 (4): 575-601.

Hillinson, W. and C. Pacini (2004). Auditor reputation and the insurance hypothesis. The information content of disclosures of financial distress of a major accounting firm. Journal of Managerial Issues 16 (1): 65-86.

Hopwood, W., J. McKeown and J. Mutchler (1989). A test of the incremental explanatory power of opinions qualified for consistency and uncertainty. Accounting Review (64): 28-48.

Keasey, K. and R. Watson (1987). Non-financial symptoms and the prediction of small company failure. A test of argenti's hypotheses. Journal of Business Finance and Accounting 14 (3): 335-354.

Kida, T. (1980). An investigation into auditor's continuity and related qualification judgements. Journal of Accounting Research (18): 506-523.

Kim, H. and S. Sohn (2010). Support vector machines for default prediction of SMEs based on technology credit. European Journal of Operational Research 201 (3): 838-846.

Krishnan, J. and J. Krishnan (1996). The role of economic trade-offs in the audit opinion decision. an empirical analysis. Journal of Accounting, Auditing and Finance (11): 565-586. 
Lennox, C. (2000). Do companies successfully engage in opinion-shopping? Evidence from the UK. Journal of Accounting and Economics (29): 321-337.

Liu, J. (2004). Macroeconomic determinants of corporate failures. evidence from the UK. Applied Economics (36): 939-945.

Loudder, M. L., I. K. Khurana, R. B. Sawyers, C. Cordery, C. Johnson, J. Lowe and R. Wunderle (1992). The information content of audit qualifications. Auditing. A Journal of Practice \& Theory 11 (1): 69-82.

Martin, D. (1977). Early warning of bank failure. Journal of Banking and Finance 1 (3): 249-176.

Matsumura, E., K. Subramanyam and R. Tucker (1997). Strategic auditor behaviour and going-concern decisions. Journal of Business Finance and Accounting 24 (6): 727-759.

McKeown, J. C., J. F. Mutchler and W. Hopwood (1991). Towards an explanation of auditor failure to modify audit reports of bankrupt companies. Auditing . A Journal of Practice \& Theory 10 (supp): 1-13.

Mensah, Y. M. (1984). An examination of the stationarity of multivariate bankruptcy prediction models. Journal of Accounting Research (22): 280-395.

Messier, W. and J. Hansen (1988). Inducing rules for expert systems development. An example using default and bankruptcy data. Management Science 34 (12): 1403-1415.

Ohlson, J. (1980). Financial ratios and the probabilistic prediction of bankruptcy. Journal of Accounting Research 18 (1): 109-131.

Peel, M., D. Peel and P. Pope (1986). Predicting corporate failure. some results for the UK corporate sector omega. The International Journal of Management Science 14 (1): 5-12.

Pozuelo, J., G. Labatut and E. Veres (2010). Análisis descriptivo de los procesos de fracaso empresarial en microempresas mediante técnicas multivariantes. Revista Europea de Dirección y Economía de la Empresa 19 (3): 47-66. 
Robinson, D. (2008). Auditor independence and auditor-provided tax service. Evidence from going-concern audit opinions prior to bankruptcy filings. Auditing: A Journal of Practice \& Theory 27 (2): 31-54.

Rodríguez, M., P. de Llano and C. Piñeiro (2010). Bankruptcy prediction models in galician companies. Application of parametric methodologies and artificial intelligence. International Conference on Applied Business \& Economics (ICABE 2010), Coruña.

Rose, P. S., W. T. Andrews and G. A. Giroux (1982). Predicting business failure. a macroeconomic perspective. Journal of Accounting, Auditing and Finance (6): 20-32.

Ruiz, E. and N. Gómez (2001). Análisis empírico de los factores que explican la mejora de la opinión de auditoría. Compra de opinión y mejora en las prácticas contables de la empresa. Revista Española de Financiación y Contabilidad 36 (134).

Sarkar, S. and R. Sriram (2001). Bayesian models for early warning of bank failures. Management Science 47 (11): 1457-1475.

Schwartz, K. and K. Menon (1985). Auditor switches by failing firms. Accounting Review (60): 248-261.

and B. Soo (1995). An analysis of form 8-K disclosures of auditor changes by firms approaching bankruptcy. Auditing: A Journal of Practice \& Theory 14 (1): 125-136.

Serrano, C. and B. Martín del Brío (1993). Predicción de la quiebra bancaria mediante el empleo de redes neuronales artificiales. Revista Española de Financiación y Contabilidad 22 (74): 153-176.

Simunic, D. (1984). Auditing, consulting and auditor independence. Journal of Accounting Research (22): 679-702.

Sun, J. and H. Li (2009). Financial distress early warning based on group decision making. Computers \& Operations Research (36): 885-906. 
Teoh, S. (1992). Auditor independence, dismissal threats, and the market reaction to auditor switches. Journal of Accounting Research (30): 1-23.

Tucker, R. R. and E. M. Matsumura (1998). Going concern judgements. An economic perspective. Behavioral Research in Accounting (10): 197-218.

Venuti, E. (2004). The going-concern assumption revisited. Assessing a company's future viability. The CPA Journal: 40-44. 